\title{
PELATIHAN LITERASI MEDIA SOSIAL TERKAIT PENANGGULANGAN HOAKS BAGI SISWA PKBM 26 BINTARO
}

\author{
Muhamad Guruh, Hendri Gunawan, Devi Putri Isnaeni, Nurdinni Tilova, \\ Henni Marlinah \\ Program Studi Manajemen \\ Universitas Pamulang \\ muhamad.guruh23@gmail.com
}

\begin{abstract}
Literacy is the ability to understand, analyze, and deconstruct media imager. The ability to do this is intended so that viewers on this matter especially students as media consumers become aware of the way media is created and accessed. Social media is a positive contributor in the advancement of technology and communication. However, the positive impact of the use of social media is often not paid attention, instead of the negative impact of social media that ultimately happens a lot, where one of them is related to the spread of hoax news Hoaxs are information that is created to cover up the actual information. In other words hoaks can also be interpreted as an effort to distort the facts using information that seems convincing but cannot be verified. Hoaks can also be interpreted as an act of obscuring the real information, by flooding a media with the wrong message in order to cover up the correct message. One of the efforts to increase media literacy is through the implementation of Community Service in the form of discussions and the provision of knowledge held at the PKBM 26 Bintro. With the aim of increasing social media literacy training related to hoax prevention, this activity is carried out by providing contemporary examples and presentations regarding the risks of hoax dispersal.
\end{abstract}

Keywords: Media Literacy, Social Media, Hoaks

\begin{abstract}
Abstrak
Literasi adalah kemampuan untuk memahami, menganalisis, dan mendekonstruksi pencitraan media. Kemampuan untuk melakukan hal ini ditujukan agar pemirsa pada hal ini khususnya Para siswa sebagai konsumen media menjadi sadar tentang cara media dibuat dan diakses. Media sosial meruakan salah satu penyumbang positif didalam kemajuan teknologi dan komunikasi. Namun dampak kegunaan media sosial yang bersifat positif kerap tidak diperhatikan, alih-alih dampak negatif media
\end{abstract}


sosial lah yang akhirnya banyak terjadi, dimana salah satunya terkait dengan penyebaran pemberitaan yang bersifat hoaks. Hoaks merupakan informasi yang direkayasa untuk menutupi informasi sebenarnya. Dengan kata lain hoaks juga bisa diartikan sebagai upaya penutarbalikan fakta menggunakan informasi yang seolah-olah meyakinkan tetapi tidak dapat diverifikasi kebenarannya. Hoaks juga bisa diartikan sebagai tindakan mengaburkan informasi yang sebenarnya, dengan cara membanjiri suatu media dengan pesan yang salah agar bisa menutupi pesan yang benar. Salah satu upaya meningkatkan literasi media adalah melalui pelaksanaan Pengabdian Kepada Masyarakat berupa diskusi dan pemberian pengetahuan yang diselenggarakan di PKBM Negeri 26 Bintro. Dengan tujuan untuk meningkatkan pelatihan literasi media sosial terkait penanggulangan hoaks, kegiatan ini dilaksanakan dengan memberikan contoh-contoh kontemporer dan pemaparan terkait risiko-risiko dari ketersebaran hoaks.

Kata Kunci : Literasi media, media sosial, hoaks

\section{A. PENDAHULUAN}

Media sosial kini telah menjadi salah satu aplikasi yang sangat digemari oleh anak muda. Tingginya tingkat penggunaan media sosial ini namun tidak dibarengi dengan kesadaran akan berbagai dampak yang dapat timbul dan mempengaruhi beragam sendi kehidupan. Berbicara tentang media sosial, tentu kita akan sering mendengar istilah tentang literasi \& hoaks.

Menurut KBBI: "Berita palsu atau berita bohong atau hoaks (bahasa inggris: hoax) adalah informasi yang sesungguhnya tidak benar, tetapi dibuat seolah-olah benar adanya". Sedangkan pengertian literasi menurut National Institute for Literacy, literasi merupakan suatu kemamuan dari tiap individu dalam membaca, menulis, berbicara, menghitung serta juga memecahkan suatu masalah pada tingkat keahlian yang diperlukan didalam suatu pekerjaan, keluarga dan masyarakat.

Media sosial meruakan salah satu penyumbang positif didalam kemajuan teknologi dan komunikasi. Namun dampak kegunaan media sosial yang bersifat positif kerap tidak diperhatikan, alih-alih dampak negatif media sosial lah yang akhirnya banyak terjadi, dimana salah satunya terkait dengan penyebaran pemberitaan yang bersifat hoaks. Disinilah peran dari literasi tersebut sangat diperlukan didalam penanggulangan terhadap berita hoaks yang beredar dikalangan masyarakat luas.

Media sosial muncul dalam media baru dan selalu mendapat sambutan yang hangat dari pengguna internet. Media sosial ini mengijinkan kita untuk dapat bertukar informasi dengan semua orang yang merupakan sesama pengguna media tersebut. Menurut Nasrullah (2015:11) media sosial adalah medium di internet yang memungkinkan pengguna merepresentasikan dirinya maupun berinteraksi, bekerjasama, berbagi, berkomunikasi dengan pengguna lain, dan membentuk ikatan sosial secara virtual. Kehadiran fitur share, like, 
hashtag, trending topic, di media sosial tidak dapat dipungkiri telah sangat berpengaruh dalam membaca minat dan konsumsi informasi khalayak.

Melalui fitur-fitur tersebut, berita dan informasi dapat dibagikan secara viral: tersebar luas dan terjadi dalam waktu singkat layaknya wabah penyakit yang disebarkan oleh virus. Hasil studi Jonah Berger dan Katherine Milkman (Struhar, 2014) menunjukkan bahwa beritaberita yang dibagikan secara viral melalui media sosial adalah berita yang mampu membangkitkan emosi positif atau negatif yang sangat kuat (high-arousal emotions). Meski demikian, disadari pula bahwa pengguna media sosial non Jurnalis umumnya tidak paham pentingnya akurasi, sering luput/tidak melakukan disiplin verifikasi serta tidak memiliki bekal cukup untuk memahami etika jurnalisme dan hukum media daring saat membagikan informasi di media sosial.

Hoaks, saat ini menjadi hal yang sangat diperhatikan dalam wacana terkait media digital dan media sosial. Berkembangnya dampak negatif hoaks tentu sangat dipengaruhi oleh rendahnya tingkat literasi media sosial. Rendahnya pengetahuan literasi media sosial dalam masyarakat pada zaman digital ini menjadi salah satu alasan terbesar pengunaan media sosial lebih ke hal- hal yang bersifat negatif ketimbang ke hal-hal yang bersifat positif.

Literasi media sosial tidak sekedar belajar cara yang benar mengunakanya tetapi justru seharusnya bagaimana belajar menggunakan media sosial yang ada saat ini untuk proses penyebaran informasi yang baik, serta teliti dalam Hal-hal yang bersifat tidak benar ataupun Hal-hal yang tidak pasti. Hal inilah yang perlu diadakannya pelatihan literasi media sosial untuk seluruh lapisan masyarakat, agar media sosial dapat digunakan dengan hal-hal yang bersifat positif, dan memberikan manfaat bagi seluruh masyarakat.

Untuk memanfaatkan kesempatan ini maka kami akan mensosialisasikan dan memberikan penyuluhan kepada siswa PKBM 26 Bintaro, dengan tema "Pelatihan Literasi Media Sosial Terkait Penanggulangan Hoaks Bagi Siswa".

Dalam program yang akan kami ajukan terdapat beberapa masalah yang ditemukan pada mitra kami yaitu PKBM 26 Bintaro, antara lain sebagai berikut;

a. Bagaimana cara meningkatkan pengetahuan literasi media sosial?

b. Bagaimana cara mengetahui dampak pemberitaan hoaks?

c. Bagaimana cara mengenali hoaks?

d. Bagaiman cara menanggulangi hoaks?

3. Solusi Yang Ditawarkan

Adapun solusi yang ditawarkan dari kegiatan pengabdian kepada masyarakat (PKM) mengedukasi para siswa agar dapat :

a. Mengetahui cara meningkatkan pengetahuan literasi media social

b. Mengetahui dampak pemberitaan hoaks

c. Mengetahui cara mengenali hoaks

d. Mengetahui cara menanggulangi hoaks

Target luaran dari dilakukannya kegiatan pengabdian kepada masyarakat (PKM) sebagai berikut:

a. Menambah pengetahuan tentang literasi dan hoaks

b. Mempertajam diri didalam menangkap informasi media social

c. Meningkatkan kemampuan menyimpulkan makna dari suatu informasi 
d. Mengoptimalkan kerja otak

e. Menambah kemampuan berfikir dan menganalisa

f. Meningkatkan fokus dan konsentrasi

\section{B. METODE PELAKSANAAN KEGIATAN}

1. Khalayak Sasaran

Khalayak sasaran kegiatan pengabdian kepada masyarakat ini adalah siswa PKBM 26 Bintaro di lingkungan Kelurahan Bintaro Kecamatan Pesanggrahan Jakarta Selatan. Dengan jumlah khalayak sasaran yaitu ... orang. Adapun yang menjadi instruktur dan narasumber dalam kegiatan ini adalah dosen-dosen prodi manajemen UNPAM dan mahasiswa prodi manajemen.

2. Tempat dan Waktu Pelaksanaan

Pelaksanaan kegiatan pengabdian kepada masyarakat bertempat di sekolah PKBM 26 Bintaro, yang dilaksanakan pada hari Rabu, 16 Oktober 2019.

3. Metode Kegiatan

Kegiatan PKM yang dilakukan pada sekolah PKBM 26 Bintaro akan menggunakan metode berikut ini :

a. Pelatihan langsung dengan tatap muka di kelas melibatkan anak anak kelas 12 dan guru di sekolah tersebut

Pelatihan dengan tatap muka di kelas atau classroom training tetaplah akan menjadi yang utama di industri pelatihan. Apapun proses evolusi yang sedang dijalani oleh kita semua, bahkan ketika online learning sedang booming di mana-mana, tetapi manusia selalu membutuhkan interaksi dengan sesamanya, begitu pula para pembelajar tetap membutuhkan sentuhan manusia yang terstruktur untuk memastikan tingginya motivasi belajar. Tidak bisa dipungkiri lagi, jika media sosial tidaklah mampu merubah imprint dari sifat manusia sebagai makhluk sosial, sebab imprint itu sendiri memiliki makna terletak di bagian paling dasar dan merupakan hasil penekanan yang kuat dan mencirikan sesuatu secara hampir permanen.

Di sinilah pelatihan tatap muka mengambil peran utama, apalagi di zaman sekarang ketika banyak ilmu dan teknologi baru yang harus disampaikan, classroom training dibutuhkan untuk membuka jalan di awal struktur belajar.

Perkembangan teknologi, kini juga telah memengaruhi gaya dan cara pengajaran di sekolah maupun di rumah. Salah satunya adalah belajar lewat video, atau secara online.

Meski cara modern ini dianggap lebih praktis dan mudah, tetapi tetap saja metode pengajaran secara konvensional yang membutuhkan adanya tatap muka dan interaksi merupakan yang paling efektif.

Jadi, dengan kata lain, penyampaian pesan yang efektif tersebut hanya bisa didapat, ketika tatap muka langsung. Begitu pula dalam belajar, ketika tatap muka maka pesan pelajaran akan tersampaikan dengan lebih efektif.

b. Forum diskusi interaktif dengan siswa di kelas

Perkembangan penggunaan media sosial sebagai sarana komunikasi ini menjadi semakin pesat setelah internet mulai dapat diakses melalui telephone seluler dan bahkan kemudian muncul istilah telepon cerdas (smartphone). 
Banyaknya jumlah pengguna media sosial di Indonesia tentu saja memunculkan kesempatan untuk mengoptimalkan kehadiran media sosial sebagai media komunikasi, sehingga kemudian memunculkan pertanyaan, bagaimana penggunaan media sosial untuk mengefektifkan cara berkomunikasi di dalam masyarakat, baik dalam bidang pemasaran, bidang politik maupun dalam bidang pendidikan.

Dengan adanya forum diskusi ini kami memberikan fasilitas kepada siswa untuk mengajukan pertanyaan-pertanyaan terkait literasi media sosial. Melalui kegiatan ini juga para siswa diberikan kesempatan untuk mengungkapkan pandangannya dalam memecahkan masalah terkait hoaks dalam kehidupan sehari-harinya.

\section{HASIL DAN PEMBAHASAN}

Menjamurnya berita palsu/hoax yang beredar pada media sosial di Indonesia seakan menjadi mata rantai yang tak ada ujungnya. Konten tersebut senantiasa diproduksi, direproduksi, kemudian disebarkan secara terus menerus hingga menjadi sebuah fenomena dan kultur yang biasa saja. Permasalahan ini sejatinya adalah buah dari euforia media berekspresi yang baru, yang memungkinkan kita untuk berujar dan membuat konten apapun tanpa terikat tatanan etika kehidupan yang baku.

Seakan kehidupan kita di media sosial berjalan secara terpisah dengan yang kita jalani pada dunia nyata. Media sosial seperti Facebook, Twitter, Instagram, Snapchat, atau Whatsapp adalah tempat dimana gosip, breaking news, dan informasi yang sedang ramai dibicarakan khalayak cepat menyebar. Facebook sendiri memiliki 1,55 milyar pengguna aktif pada 2016, yang setiap penggunanya menghabiskan paling tidak 20 menit per hari untuk membaca informasi terbaru pada lini masa mereka. Lebih jauh, populasi pengguna ini akan terus meningkat, hingga diprediksi pengguna aktif media sosial di seluruh dunia akan mencapai 2,72 milyar pada 2029, sekitar sepertiga dari populasi dunia (Roese, 2018:314). Hari ini, media sosial lebih berfungsi sebagai tempat pertemuan khalayak untuk bertukar berita, potongan-potongan informasi dan rekomendasi satu sama lain.

Informasi yang beredar di kanal-kanal media sosial tak jarang mengandung framing dan bumbu tambahan, bahkan praktik memelintir informasi yang memicu kaburnya batas antara berita palsu dengan yang akurat. Data Kemenkominfo menyebutkan bahwa ada sekitar 800.000 situs di Indonesia yang terindikasi sebagai penyebar informasi palsu. Pada 2014 saja, terdapat 761.126 situs yang diblokir karena konten berita palsu. Pada 2015 angkanya terus naik hingga mencapai 766.394 situs. Melengkapi data tersebut, menurut The Jakarta Post, sejak 2008 lalu sebanyak 144 orang telah diproses hukum karena kasus ujaran kebencian dan peredaran berita palsu di jagad media sosial. Salah satu hal yang menarik untuk didiskusikan adalah banyaknya warganet yang merasa berhak untuk berujar apapun di media sosial dengan menggunakan payung pembenaran kebebasan berpendapat.

Ada beberapa cara yang bisa kita lakukan dalam menghadapi situasi saat ini di mana semua berita tersebar dengan mudah dan cepat sehingga hal itu bisa menjadi pemicu masalah baru karena kadang kita tidak lagi memperhatikan isi berita atau cerita dari informasi yang beredara di masyarakat saat ini hal ini karena tingkat literasi yang masih rendah. oleh karena hal ini kita akan memberikan beberapa solusi.

1. Gerakan Literasi Sekolah 
Gerakan ini sengan di galakan kiat mengajak Siswa mulai gemar membaca, tanamkan dalam diri siswa bahwa waktu luang itu diciptakan, bukan ditunggu. Kegiatan pembelajaran tidak dapat di lepasakan dari kegaitan membaca, perlu kita tekanankan bahwa belajar tidak hanya di lakukan di dalam kelas tapi bisa juga di luar kelas, demikian juga dengan kegiatan membaca bisa dilakukan bukan hanya membaca mata pelajaran bisa juga membaca berita yang saat ini sedang beredar di masyarakat dari berbagai sumber, kemudian mengecek kebenaranya dan guru beran aktif memberikan keteladanan penerapan budaya literasi di sekolahnya. Program ini harus di pantau kegiatannya selama berjalan secara teratur dan berkelanjutan.

2. Pelatihan memahami judul berita yang beredar

Berita hoax seringkali menggunakan judul sensasional yang provokatif, misalnya dengan langsung menudingkan jari ke pihak tertentu. Isinya pun bisa diambil dari berita media resmi, hanya saja diubah-ubah agar menimbulkan persepsi sesuai yang dikehendaki sang pembuat berita palsu itu.

3. Pelatihan mengecek alamat situs

Untuk informasi yang diperoleh dari website atau mencantumkan link, cermatilah alamat URL situs dimaksud. Berita yang berasal dari situs media yang sudah terverifikasi Dewan Pers akan lebih mudah diminta pertanggungjawabannya. Menurut catatan Dewan Pers, di Indonesia terdapat sekitar 43.000 situs di Indonesia yang mengklaim sebagai portal berita. Dari jumlah tersebut, yang sudah terverifikasi sebagai situs berita resmi tak sampai 300 . Artinya, terdapat setidaknya puluhan ribu situs yang berpotensi menyebarkan berita palsu di internet yang mesti diwaspadai.

4. Pelatihan Periksa fakta dan Cek keaslian foto

Perhatikan keberimbangan sumber berita. Jika hanya ada satu sumber, pembaca tidak bisa mendapatkan gambaran yang utuh. Hal lain yang perlu diamati adalah perbedaan antara berita yang dibuat berdasarkan fakta dan opini. Fakta adalah peristiwa yang terjadi dengan kesaksian dan bukti, sementara opini adalah pendapat dan kesan dari penulis berita, sehingga memiliki kecenderungan untuk bersifat subyektif. Cek keaslian foto Dier teknologi digital saat ini, bukan hanya konten berupa teks yang bisa dimanipulasi, melainkan juga konten lain berupa foto atau video. Ada kalanya pembuat berita palsu juga mengedit foto untuk memprovokasi pembaca. Cara untuk mengecek keaslian foto bisa dengan memanfaatkan mesin pencari Google, yakni dengan melakukan drag-and-drop ke kolom pencarian Google Images. Hasil pencarian akan menyajikan gambar-gambar serupa yang terdapat di internet sehingga bisa dibandingkan.

\section{KESIMPULAN DAN SARAN}

1. Kesimpulan

a. Berita hoax merupakan berita yang sangat membahayakan karena berisi berita tidak benar yang dampaknya dapat menimbulkan kegaduhan yang akhirnya akan memecah belah persaudaraan antar siswa.

b. Kita harus waspada terhadap berita hoax. Kita dapat memilih berita dengan cara mengidentifikasi apakah berita tersebut hoax atau benar. Siswa perlu dibekali dengan pelatihan literasi media sosial agar mampu mengakses, menganalisis, mengevaluasi, 
dan mengkomunikasikan isi pesan media. Literasi media sosial bertujuan untuk mengembangkan keterampilan berpikir kritis terhadap isi media.

c. Setiap individu dapat lebih kritis menanggapi apa yang mereka lihat, dengar, dan baca. Literasi media sosial sebagai sarana filter berita hoax bagi siswa. Diharapkan dengan literasi media sosial dapat menumbuhkan kesadaran akan pentingnya menjadi pengguna media sosial yang bertanggung jawab dan dapat dijadikan bekal pengetahuan untuk pengguna dalam melakukan filter terhadap berita yang diterimanya sehingga pengguna media benar-benar mendapatkan informasi yang bernilai dan tidak mudah terjebak oleh informasi hoax.

2. Saran

Berdasarkan pengalaman dari pelaksanaan kegiatan ini maka dapat diajukan saran sebagai berikut:

a. Diharapkan kedepannya dapat bekerja sama dengan para ahli teknologi dan komunikasi, agar siswa mendapatkan wawasan yang lebih luas.

b. Diharapkan kegiatan pelatihan literasi media sosial ini tidak hanya dilaksanakan dipendidikan menengah, namun dapat dilaksanakan mulai dari pendidikan dasar sampai dengan para pekerja, karena saat ini setiap orang bersahabat dengan media sosial dalam kehidupannya.

\section{DAFTAR PUSTAKA}

Achmad, A. (2018). "Pentingnya Literasi Media Sosial Terhadap Masyarakat",https://www.kompasiana.com/alyshachmad/5c07efda6ddcae24f301bff9/penti ngnya-literasi-media-sosial-terhadap-masyarakat?page=all

Iriantara, Y. (2009). Literasi Media (Apa. Mengapa, Bagaimana). Simbiosa Rekatama Media: Bandung.

Lesmana, G. N. A. “Analisis Pengaruh Media Sosial Twitter Terhadap Pembentukan Brand Attachment (Studi: PT. XL AXIATA”), Tesis Universitas Indonesia.

Nugroho, A. S, Tips Menghadapi Hoax dan Spam. www.ilmukomputer.com.

Rahmawan, D. (2019) Pelatihan Literasi Media Sosial Terkait Penanggulangan Hoaks Bagi Siswa SMA. Jurnal Unpad.

Tambruka, A. (2013). Literasi Media. PT RajaGrafindo Persada: Jakarta.

Tim pusat hums kementerian perdagangan RI. (2014 ). Panduan Optimalisasi Media Sosial untuk Kementerian Perdagangan RI", Jakarta.

ZonaSultra.com "Ini Cara Mengatasi Berita "Hoax" di Dunia Maya".

http://zonasultra.com/ini-cara-mengatasi-berita-hoax-di-dunia-maya.html 